\title{
34 Haftalık Gebe Hastanın Mesanesinde Rahim İçi Araç Migrasyonuna Bağlı Oluşan Taş
}

\author{
Vesical Calculus Formation in a 34 Week Pregnant Patients Bladder; Due to Migrated Copper-T \\ Intrauterine Contraceptive Device
}

\section{Cagatay Ozsoy', Selim Tas', Kaan Karamik', Hakan Anil'², İbrahim Erol', Ekrem Islamoglu'}

${ }^{1}$ Department of Urology, University of Health Sciences, Antalya Training And Research Hospital, Antalya, Turkey

2 Department of Urology, University of Health Sciences, Adana City Hospital, Adana, Turkey

Geliş tarihi (Submitted): 10.01.2019

Kabul tarihi (Accepted): 18.07.2019

Yazıșma / Correspondence

Cagatay Ozsoy, MD

ORCID: 0000-0002-2124-865X

University of Health Sciences, Antalya

Training And Research Hospital

07100 Muratpaşa, Antalya, Turkey

Tel: +90 5376814608

E-mail: cagatayozsoy89@gmail.com

\section{c) (i) (5)}

Bu eser Creative Commons AtıfGayriTicari 4.0 Uluslararası Lisansı ile lisanslanmıştır.

\section{Özet}

35 yaşında gebe hasta son $\ddot{u}$ ç aydır olan acil idrar hissi, dizüri ve pollaküri şikayetleriyle tarafımıza başvurdu. Yapılan üriner ultrasonografide mesane içerisinde bir rahim içi araç ve ona yapışık haldeki kalkül görüldü. Hastanın özgeçmişi sorgulandığında 5 sene önce kontrasepsiyon amaçlı rahim içi araç uygulandığı öğrenildi. Mesane içi yabancı cisme bağlı oluşan idrar yolu enfeksiyonu için doğuma kadar uygun antibiyotiklerle tedavi edildi. Doğum sonrası yapılan sistoskopiyle rahim içi araç ve beraberindeki kalkül mesaneden temizlendi.

Anahtar Kelimeler Migrasyon, RİA, Mesane taşı

\begin{abstract}
A 35-year-old pregnant patient presented with urgency, dysuria and pollakiuria for the last three months. Ultrasonography revealed an intrauterine contraceptive device (IUCD) and a calculus attached to it in her bladder. She had undergone an IUCD insertion 5 years earlier. She was treated with proper antibiotics for urinary tract infections until giving birth. After birth IUCD with stone was removed via

Keywords: Migrated, IUCD, Bladder
\end{abstract} cystoscopy. stone 


\section{INTRODUCTION}

The intrauterine contraceptive device (IUCD) is a well-known contraceptive method. It has been in use for many years. Insertion of IUCD has many complications. These complications include uterine perforation, pelvic abscess, septic abortion, ectopic pregnancy and migration into adjacent organs (1). Uterine perforation by an IUCD is not common. The overall incidence is about 0,87 per 1000 insertions (2). IUCD migration to bladder and stone formation around it are extremely rare complications. In this case, we reported a 34-week pregnant woman who diagnosed bladder stone due to migrated IUCD and cured with an endoscopic procedure after giving birth.

\section{CASE REPORT}

The patient was a 35-year-old and 34-week pregnant woman. She presented with urgency, dysuria and pollakiuria for the last three months. She had been treated with antibiotics for urinary tract infections during the last three months in routine obstetric visits. No urinary tract imagining was performed during this time. After persistence of patient's complaints, she was referred to us. Additional history revealed that she had an IUCD insertion about five years ago. But one year after the insertion in a gynecologic examination, she was told that there was no IUCD in her uterus, and it might have been dropped spontaneously from the vagina. There were no abnormalities on physical examination. Urinalysis identified 90 leukocytes $\mathrm{p} /$ hpf and 35 erythrocytes p/hpf. Urine culture showed $100000 \mathrm{CFU} / \mathrm{ML}$ Enterococcus spp. An ultrasound of the bladder revealed an amorphous $35 \mathrm{~mm}$ intravesical lesion with distal acoustic shadowing compatible with calculus or foreign body (Figure 1). An X-ray of kidney-ureter-bladder (KUB) and cystoscopic examination planned for exact diagnosis. However, X-ray image and cystoscopic examination were postponed until delivery. She was followed by urinalysis and urine culture and treated with proper antibiotics. In 39 weeks of pregnancy, she gave birth with a c section and there was no sign of IUCD in her uterus. One month after birth she was examined with X-ray of KUB. A

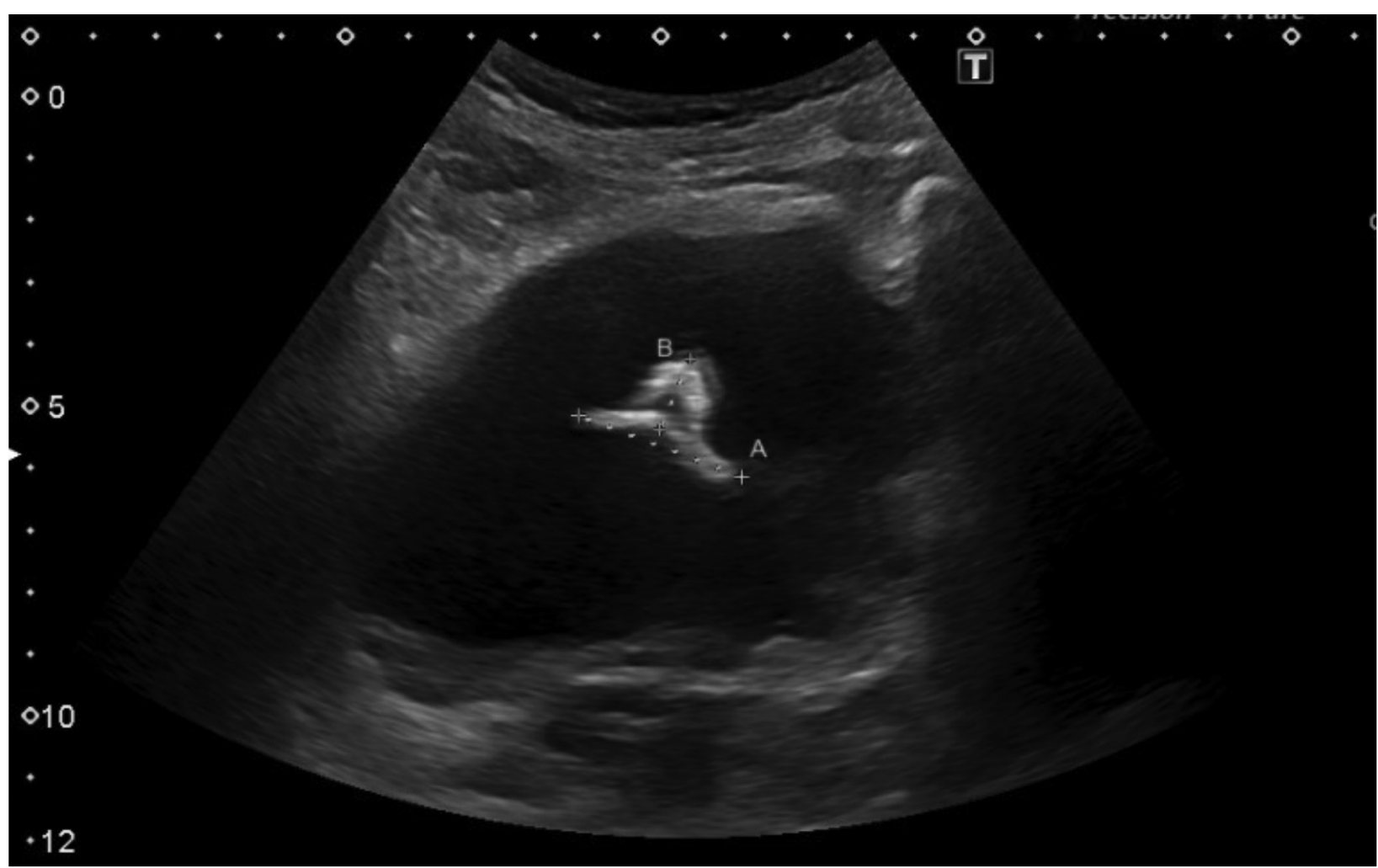

Figure 1: Amorphous $35 \mathrm{~mm}$ intravesical lesion with distal acoustic shadowing. 


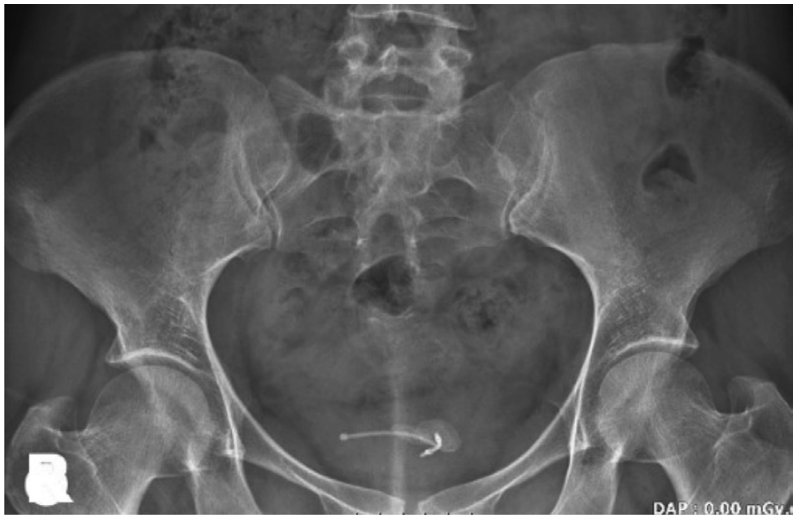

Figure 2: A copper-T İUCD and bladder stone around it.

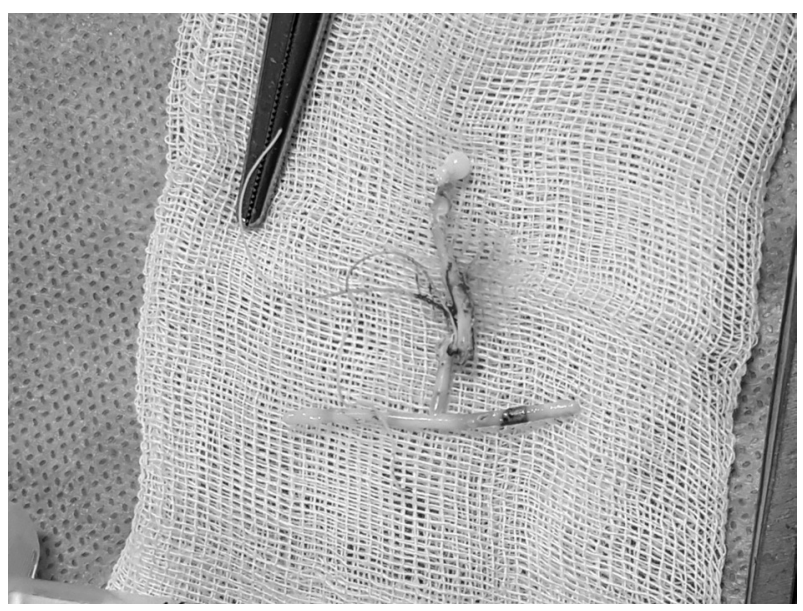

Figure 3: Intrauterine device removed from the bladder

copper-T İUCD and $35 \mathrm{~mm}$ bladder stone around it was seen (Figure 2). Rigid cystoscopy performed and it was seen that one part of IUCD wire was penetrating the mucosa on the posterior wall and the other part was surrounded with a large calculus. There was no bladder perforation. Calculus was crushed completely with holmium laser and removed from the bladder. The mucosal portion incised with holmium laser, and IUCD has taken outside with endoscopic forceps (Figure 3). The patient discharged on the 1 st postoperative day. The urethral catheter was removed on the $3 \mathrm{rd}$ postoperative day. By the end of the two weeks, all her symptoms had regressed.

\section{DISCUSSION}

Intravesical migration of IUCD is a very rare complication (2). The overall reported incidence of IUCD perforation is about 0.87 per 1000 insertion (2). This includes the pelvis, peritoneal cavity, and adjacent organs.

The experience of the practitioner is one of the most significant factor to predict the misplacement of IUCDs (3). IUCD placements should be performed by experienced practitioners or under supervision. Periodic follow-up must be done after insertion.

The exact mechanism of migration or when it occurs is not clear. There are a lot of mechanisms suggested to explain the migration. Overlooking the iatrogenic uterine perforation, peritoneal fluid movements, spontaneous uterine contractions, involuntary bladder contractions and gut peristalsis are some of the suspected reasons (4). Perforations are mostly diagnose at the time of insertion ( $86 \%)$ and indicated by pain and bleeding. However, some perforations remain undiagnosed for several years (3). The longest interval between insertion of an IUCD and diagnosis of its migration into the bladder is 25 years (5).

Bladder stones are unusual in women. A woman with a bladder stone should raise the suspicion of the presence of a foreign body (6). Foreign bodies can play a role as a nidus for calcium precipitation and stone formation in the bladder (7).

In detecting the migrated IUCDs plain X-ray, USG and cystoscopy are usable methods (8). The plain film diagnoses a bladder stone with an attached IUCD (9). We believe that cystoscopy is a perfect tool to diagnose the migration of an IUCD into the bladder. It also gives the practitioner a chance to treat the patient. USG has also been reported to be an excellent tool for diagnosis of lost IUCDs (10). All migrated intravesical IUCDs should remove with cystoscopy. If it's not possible to remove it endoscopically, open or laparoscopic surgery should be considered.

\section{CONCLUSION}

IUCD placements should be performed by experienced practitioners or under supervision. Periodic follow-up must be done after insertion. Intravesical migration of an IUCD should be considered in any woman with bladder stone and recurrent urinary tract infection who undergone previous IUCD insertion. 
Intravesical migrated IUCDs can treat with endoscopic, laparoscopic or open surgery.

\section{REFERENCES}

1. el-Diasty TA, Shokeir AA, el-Gharib MS, Sherif LS, Shamaa MA. Bladder stone: a complication of intravesical migration of Lippes loop. Scand J Urol Nephrol 1993;27:279-280.

2. Markovitch O, Klein Z, Gidoni Y, Holzinger M, Beyth Y. Extrauterine mislocated IUD: is surgical removal mandatory? Contraception 2002;66:105-108.

3. Harrison-Woolrych M, Ashton J, Coulter D. Uterine perforation on intrauterine device insertion: is the incidence higher than previously reported? Contraception 2003;67:53-56.

4. Eke N, Okpani AO. Extrauterine translocated contraceptive device: a presentation of five cases and revisit of the enigmatic perforation and migration. Afr J Reprod Health 2003;7:117-123.
5. Al-Awadi KA, Zaghloul AS, Kehinde EO. Symptomatic Secondary Vesical Calculus Formed on an Intrauterine Contraceptive Device Inserted 25 Years Previously. Urol Int 2011;86:483-486.

6. Schoenfeld A, Pardo J, Engelstein D, Ovadia J, Servadio C. Bladder perforation by an intrauterine device. J Clin Ultrasound 1991;19:175-177.

7. Atasoy C, Fitoz S, and Akyar S. Bladder stone caused by an ectopic intrauterine contraceptive device: case report. Can Assoc Radiol J 2001;52: 33-34.

8. Iqbal Singh. Intravesical $\mathrm{Cu}-\mathrm{T}$ emigration: an atypical and infrequent cause of vesical calculus. Int Urol Nephrol 2007;39:457-459.

9. Zakin D. Perforation of the bladder by the intrauterine device. Obstet Gynecol Surv 1984;39:59-66.

10. Mahmut Yazicioglu K, Ozdemir H, Ozkan P. Migration of an intrauterine contraceptive device to the urinary bladder: sonographic findings. J Clin Ultrasound 2002;230:496-498. 